\title{
STUDY THE EFFECT OF DUST DEPOSITION ON SOLAR PHOTOVOLTAIC AND SOLAR RADIATION
}

\author{
El-Sybaee I. M. ; A. A. El-keway*; M. I. Elmeadawy* and
}

\author{
M. A. Abdel-Maksoud**
}

ABSTRACT

The aim of this research was study the effect of dust deposition on solar radiation and solar photovoltaic panel. A theoretical calculation was done and experiments were carried out at Mariout Research Station, ElAmria-Alexandria-Desert Research Center. To study the effect of dust deposition two square plates of glass $(20 \times 20 \mathrm{~cm})$ and three pyrnometers were used, the first plate (the control) was cleaned daily and the other was used to determine the solar radiation. The period of the experiment is 175 days from $14^{\text {th }}$ march to $26^{\text {th }}$ August 2017. From the experiments; the dust deposition reduces the amount of solar radiation which is falling on the solar panel and creates shadow effect. With the passage of time the density of dust on the panel increases. And this reduces the electric power of the solar panel,. From the data, there was power reduction up to 51.12 $\%$. The efficiency of the solar photovoltaic panel system was reduced from 15.9 to $7.88 \%$ for clean and unclean modules respectively. The total correction solar radiations for the experimental period are 37.4 and $18.28\left(\mathrm{~kW} . \mathrm{h} / \mathrm{m}^{2}\right)$ for clean and unclean modules respectively. The unclean module with dust deposition, showed total output power (24.88\%) less than the clean module for the period of 25 weeks.

Keyword: Efficiency of solar photovoltaic panel, Efficiency reduction.

\section{INTRODUCTION}

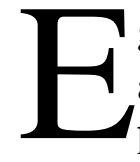
gypt is in advantageous position with solar energy. In 1991, solar atlas for Egypt was issued indicating that it enjoys 2900-3200 hours of sunshine annually with annual direct normal energy density $1970-3200 \mathrm{kWh} / \mathrm{m}^{2}$, Energy is a major drive of modern economic development .Comsan. (2010). Hassan, et al (2005) Cement dust is considered the main source of pollution; this dust is often present in the atmosphere in the Helwan area and is shown to reduce both the short circuit current and the open circuit voltage when deposited onto the surface of photovoltaic cells.

* Agric. Eng. Res. Inst. (AEnRI), Giza. - ** Mariout Research Station, D.R.C. 
The rate of decrease in these parameters depends mainly on the rate of dust deposition. The decrease in efficiency for polycrystalline silicon solar cells (Poly-Si) 66\% after six months without panel cleaning. The decrease in efficiency for Poly-Si is $9 \%$ due to the suspended particles with panel cleaning. Chaichan, et al (2015) the obtained results indicate that the air pollution may deteriorate the PV cell performance, even with a short period of two months of the cells' outdoor exposure without cleaning. The polluted PV cells produced power reduced to approximately $12 \%$ compared to the clean cell. While the naturally cleaned cell lost about $8 \%$ compared to the clean cell. The maximum power/week increased for the cleaned cell, compared to the polluted and naturally cleaned cells. The collected pollutants inspections clarified high rates of hydrocarbon particulate matters that resulted from cars exhausts.

Zorrilla-Casanova J. et al (2011) the mean of the daily energy loss along a year caused by dust deposited on the surface of the PV module is around $4.4 \%$. In long periods without rain, daily energy losses can be higher than 20\%. In addition, the irradiance losses are not constant throughout the day and are strongly dependent on the sunlight incident angle and the ratio between diffuse and direct radiations. When studied as a function of solar time, the irradiance losses are symmetric with respect noon, where they reach the minimum value. We also propose a simple theoretical model that, taking into account the percentage of dirty surface and the diffuse/direct radiation ratio, accounts for the qualitative behavior of the irradiance losses during the day. Mohamed A. O., and A. Hasan (2012) this paper investigated a framework of weekly cleaning on PV modules array throughout the period from February to May. The results indicated a significant gradual decrease of power, so frequent weekly water washing maintaining performance losses between $(2-2.5 \%)$. It is important feature of water washing on the modules surfaces deemed more reliable to recover power loss. Samadhiya A. and Ruchi P. (2016) Solar irradiance has the greatest impact on the power output of a PV system. Beyond irradiance, weather conditions such as ambient temperature along with several other factors (e.g. angle of incidence (AOI), dust, etc. may also affect a module's or an array's power output and energy production. To this end, module temperature is influenced by the ambient temperature, cloud patterns and wind speed, while the rate of temperature 
change depends also on the PV material and position of the frame. Grubišić-Čabo F. et al., (2016) Shown that active water cooling is the best choice when increasing electrical efficiency is the main goal. Therefore, research aim in the future should be implementation of effective active water cooling of PV panel. Additional solar panel at the water outlet can be proposed to increase water outlet temperature, thus increasing overall efficiency. For reducing pumping costs, front surface cooling is proposed as more economical solution, especially in hot climate conditions. One obvious drawback of front side cooling could be water evaporation, which would require continuous replenishment of evaporated water. Sulaiman S. A. et al., (2011) the effect of presence of dust was studied using artificial dust (mud and talcum) under a constant irradiance conducted in an indoor lab. Dust has an effect on the performance of solar PV panel. The reduction in the peak power generated can be up to $18 \%$. It was also shown that under greater irradiation, the effect of dust became slightly reduced but not negligible. In the study, it was also shown that the differences between the results obtained by using mud and talcum were generally small; i.e. about $6 \%$. Hence, in practice, dust must be removed from the surface of solar PV panel in order to ensure highest performance, given the fact that it is still a costly form of energy source and the short lifespan it has. It was found from the study that the accumulated dust on the surface of photovoltaic solar panel can reduce the system's efficiency by up to $50 \%$.

Mekhilef S. et al., (2012) mentioned that dust deposition and settlement on the surface of PV cells can drop the efficiency. Likewise almost always humidity causes degradation in solar cell efficiency. By increased wind velocity more heat can be removed from the PV cell surface. In the same vein, higher air velocity lowers the relative humidity of the atmospheric air in the surroundings which in turn leads to better efficiency. On the contrary, wind lifts dust and scatters it in the environment resulting in shading and poor performance of PV cells.

\section{Methodology}

\section{MATERIAL AND METHODS}

The main purpose of this study was measure and calculates losses caused by the accumulation of dust on the surface of photovoltaic modules. Three pyranometers were used to measure the average of solar radiation 
every fifteen minutes. One of the pyranometers measured the solar radiation directly, the second pyranometer put down a square plate of glass $(20 \times 20 \mathrm{~cm})$ and it was cleaned daily. The third one put down of the unclean square plate of glass $(20 \times 20 \mathrm{~cm})$ throughout the experiment period. (175 day from $14^{\text {th }}$ march to $26^{\text {th }}$ august 2017.

A Campel scientific CR10X data logger was programmed to store the average values of measurement for all sensors at one-minute intervals. By comparing recorded irradiance values sensed by the three pyranometers. The Campel scientific CR10X data logger as shown in Fig (1).

At first the collected data was correct to remove the effect of glass reflection by using the three pyranometers. The effect of the reflection was calculated by subtract the clean and direct pyranometers value.
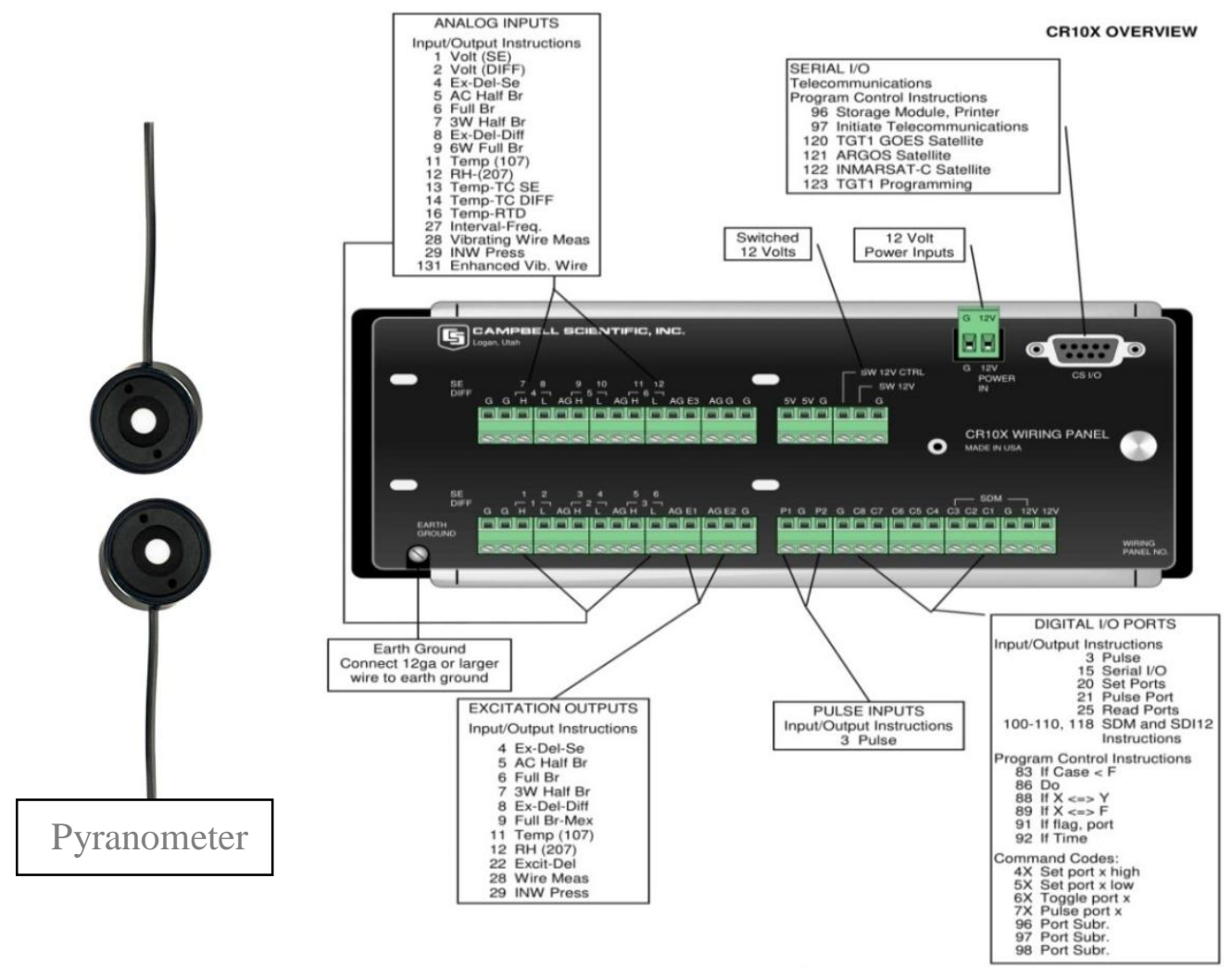

Fig (1): The Campel scientific CR10X data logger

Daily irradiation losses caused by dust are calculated comparing irradiation values sensed by the clean and the unclean glasses plates. 
Along the experimental period, the weather in autumn and summer was dry. The data for the studied period was recorded. In the other side, the effect of dust was investigated by using two commercially available photovoltaic modules.

The panels were placed on the roof top of Mariout Research Station, ElAmria-Alexandria- Desert Research Center (Latitude 31.15 N and 29.90 E) on a rack with a fixed flat angle (Fig 2). The manufacturer rated power of each module was $150 \mathrm{~W}$. The Specifications of photovoltaic modules are shown in Table (1). During the study, two modules (clean and unclean) were remained in outdoor atmosphere for the experimental period.

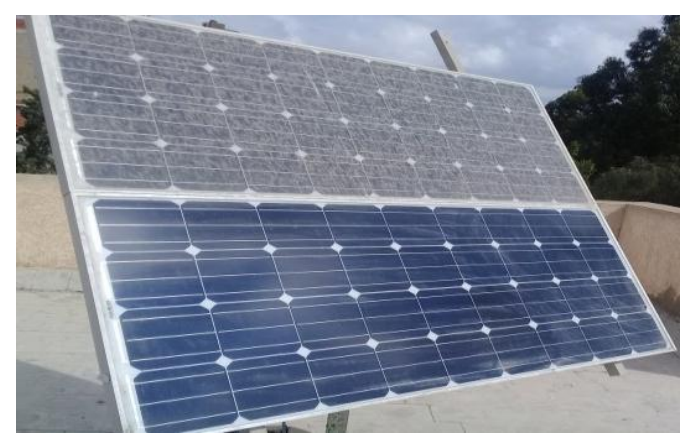

Fig (2) Clean and unclean for PV modules

Table (1) Specifications of photovoltaic modules

\begin{tabular}{|c|c|}
\hline Specification of solar module & Rating \\
\hline $\mathrm{V}_{\mathrm{oc}}$ & $21.6 \mathrm{~V}$ \\
\hline $\mathrm{I}_{\mathrm{sc}}$ & $9.25 \mathrm{Amps}$ \\
\hline Rated current & $8.333 \mathrm{Amps}$ \\
\hline Rated voltage & $18 \mathrm{~V}$ \\
\hline Maximum power point $(\mathrm{MPP})$ & $150 \mathrm{Watt}$ \\
\hline Temperature of module & $25^{\circ} \mathrm{C}$ \\
\hline Area & $0.9425 \mathrm{~m}^{2}$ \\
\hline Max serial fuse & $15 \mathrm{Amps}$ \\
\hline Temperature coefficient of $\mathrm{I}_{\mathrm{sc}}\left(\% /^{\circ} \mathrm{C}\right)$ & +0.06 \\
\hline Temperature coefficient of $\mathrm{V}_{\mathrm{oc}}\left(\%{ }^{\circ} \mathrm{C}\right)$ & -0.36 \\
\hline Temperature coefficient of $\mathrm{P}_{\mathrm{M}}\left(\% /^{\circ} \mathrm{C}\right)$ & -0.5 \\
\hline
\end{tabular}


The cleaned module was cleaned every day but the unclean module wasn't cleaned during the period of the experimental to accumulate dust naturally on the panel surface. The effect of dust was determined by comparing the output parameters of clean and unclean modules.

A variable heavy-duty resistor is connected to the panel it started from lower resistance to higher. This led to the panel voltage increased from zero toward open circuit in steps of approximately $21.6 \mathrm{~V}$. Current and voltage for each resistor are measured and recorded as shown in Fig (3). Voltage and current measured by the voltmeter and ammeter respectively.

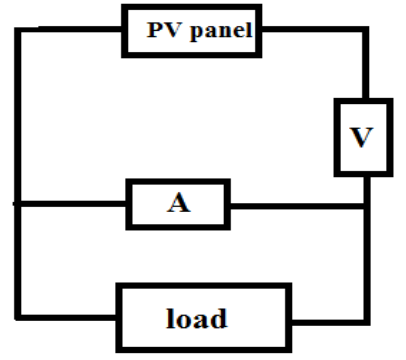

Fig (3). Schematic diagram of the circuit

\section{Digital multitier}

Two digital multimeters (with accuracy of: $+1 \%$ for DC current and + $0.09 \%$ for the DC volt) along the variable resistance (300W) were used to measure current and voltage.

The maximum power was calculated using the following equation.

$$
p_{\max }=I_{\max } x V_{\max }
$$

Module efficiency was calculated as Following:

$\eta_{\text {module }}=\frac{p_{\max }}{G \times A}$

Reduction power $(\%)=\frac{p_{\text {clean }}-p_{\text {unclean }}}{p_{\text {clean }}} \times 100$

Reduction in module efficiency $(\%)=\frac{\eta_{\text {clean }}-\eta_{\text {unclean }}}{\eta_{\text {clean }}} \times 100$

$$
H L(\%)=100\left(\frac{H_{c c-} H_{D c}}{H_{c c}}\right)
$$

(Chaichan et al (2015))

Where:-
A : Actual area of module
G : Global solar irradiance
$I_{\max }:$ maximum current 


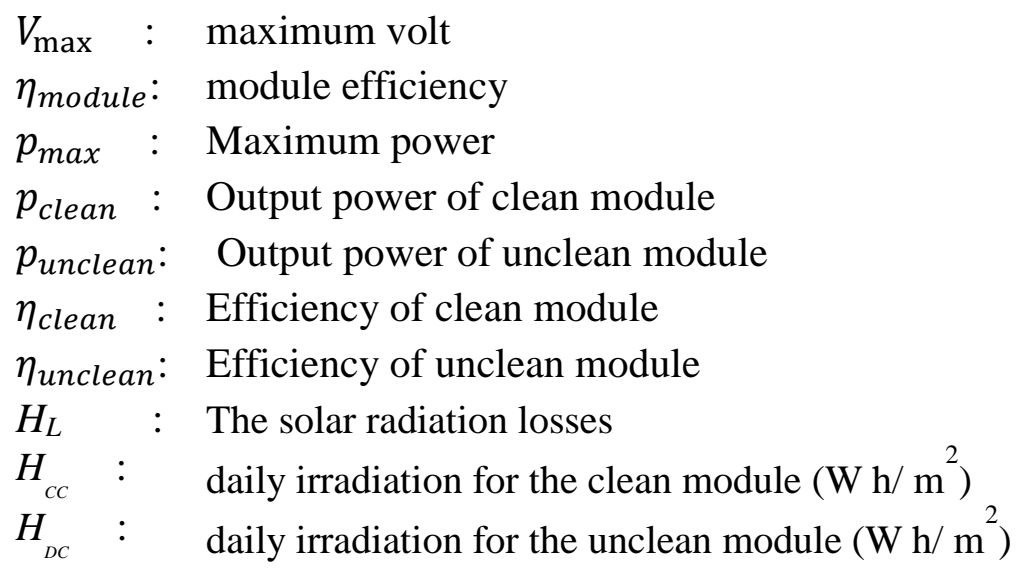

\section{RESULT AND DISCUSSION}

The effect of dust accumulation on solar Irradiation between the clean and unclean square plates of glasses

Fig (4) Showed that the Effect of dust accumulation on solar Irradiation between clean and unclean square plates of glasses. The results indicated that solar radiation decreased continuously with increasing accumulated dust every day.

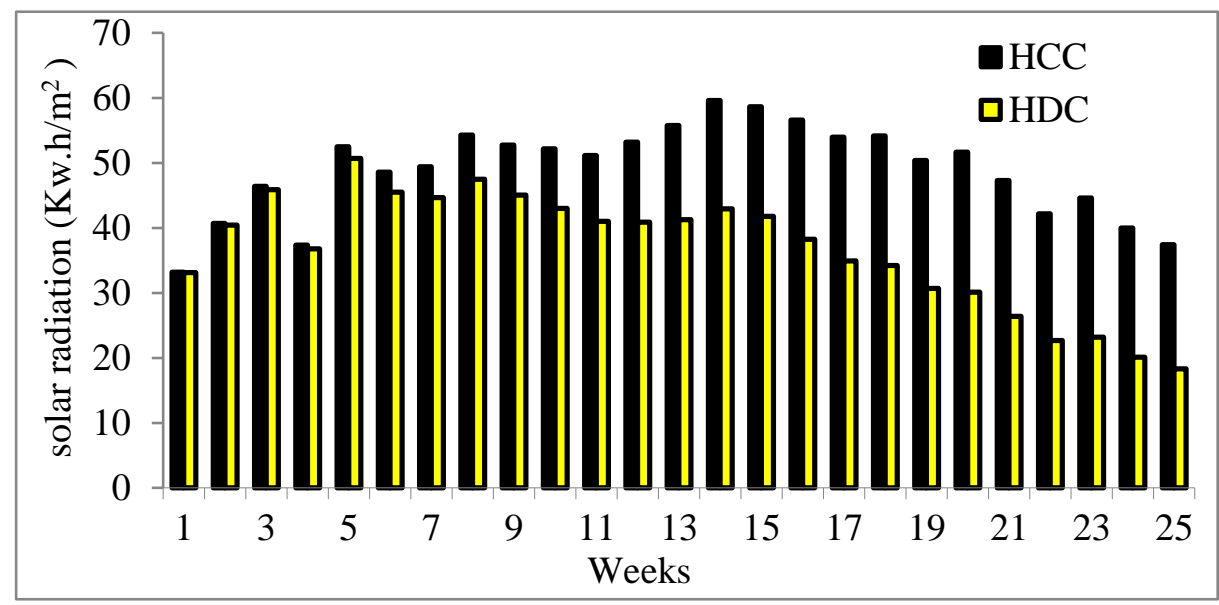

Fig (4) Effect of dust accumulation on solar Irradiation between the clean and unclean square plates of glasses

The difference of correction solar radiation between the (clean and unclean) is very small at the first week [33.17 and $33.09\left(\mathrm{~kW} . \mathrm{h} / \mathrm{m}^{2}\right)$ ] respectively. With the passage of time, the solar radiation of unclean 
square plates of glasses gradually decreased compared to the clean square plates of glasses. This is due to the dust deposition on its surface. The trends of weekly total solar radiation reduction can be seen with unclean square plates of glass compared to the clean one. The total solar radiations of some weeks for all square plates of glasses were lower than the other weeks; this was due to the fact that most of these reading days were cloudy. The maximum correction solar radiation was found at week number (14) [59.6 and $42.93\left(\mathrm{~kW} . \mathrm{h} / \mathrm{m}^{2}\right)$ ] for clean and unclean square plates of glasses respectively. After 25 week, the total correction solar radiation between the two square plates of glasses (clean and unclean) showed a big difference in the solar radiation [37.4 and 18.28 (kW.h / $\left.\mathrm{m}^{2}\right)$ ] respectively.

\section{The effect of dust on the output power of PV modules}

Fig (5) showed that the Effect of dust accumulation on output power between the clean and unclean module. The results indicated that output power decreased continuously with increasing accumulated dust every day. The difference of module power between the clean and unclean was very small at the first week, the difference in the output power [4.98 and 4.96 ( $\mathrm{kW} /$ week)] for clean and unclean modules respectively. With the passage of time, the output power of unclean module gradually decreased compared to the clean module due to the dust deposition on its surface.

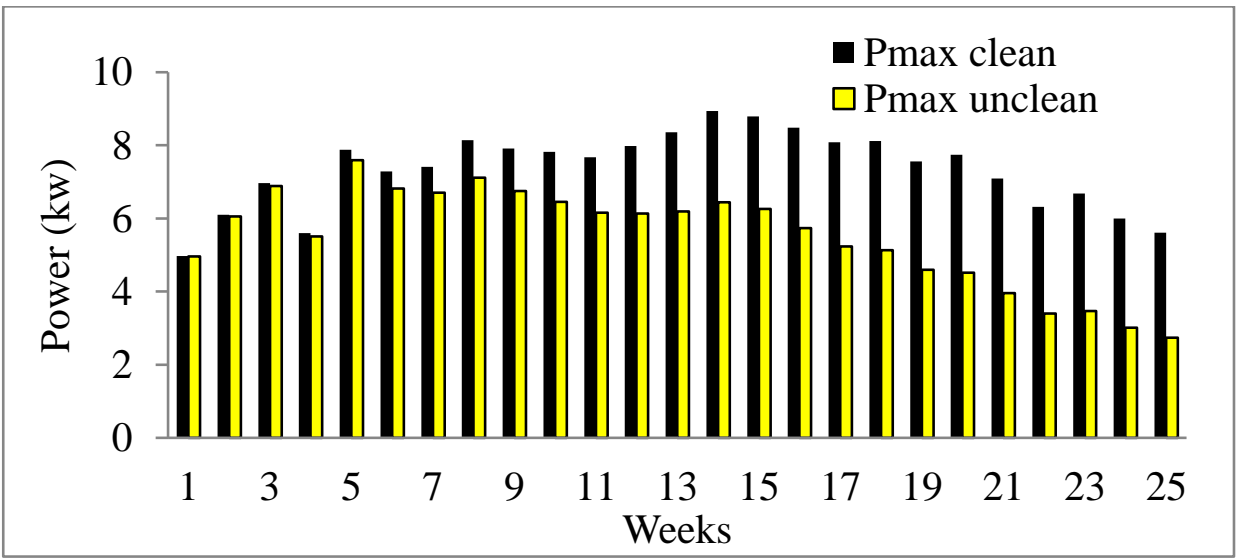

Fig (5) Effect of dust on the output power between the clean and unclean of PV modules

The total output power of all modules were lower than the other weeks as shown in fig (6), which was due to the fact that most of these reading 
days were cloudy. After 25 week, both the modules (clean and unclean) showed a big difference in the output power (5.61 and $2.74 \mathrm{~kW}$ ) respectively. The unclean module with dust deposition, showed total output power $(24.88 \%)$ less than the clean module for the period of 25 weeks.

\section{The effect of dust on the module efficiency of PV modules}

Fig (6) showed that the Effect of dust accumulation on module efficiency between the clean and unclean module. The results showed that the efficiency of unclean module as the accumulated dust decreased every day. However, the efficiency of the clean module was nearly constant (15.9\%) for the time experiment. The module efficiency depends upon the output power of PV module and solar irradiance it degrades with the dust accumulation on PV module surface. The module efficiency after 25 weeks of study was (15.9 and $7.88 \%$ ) for clean and unclean module respectively.

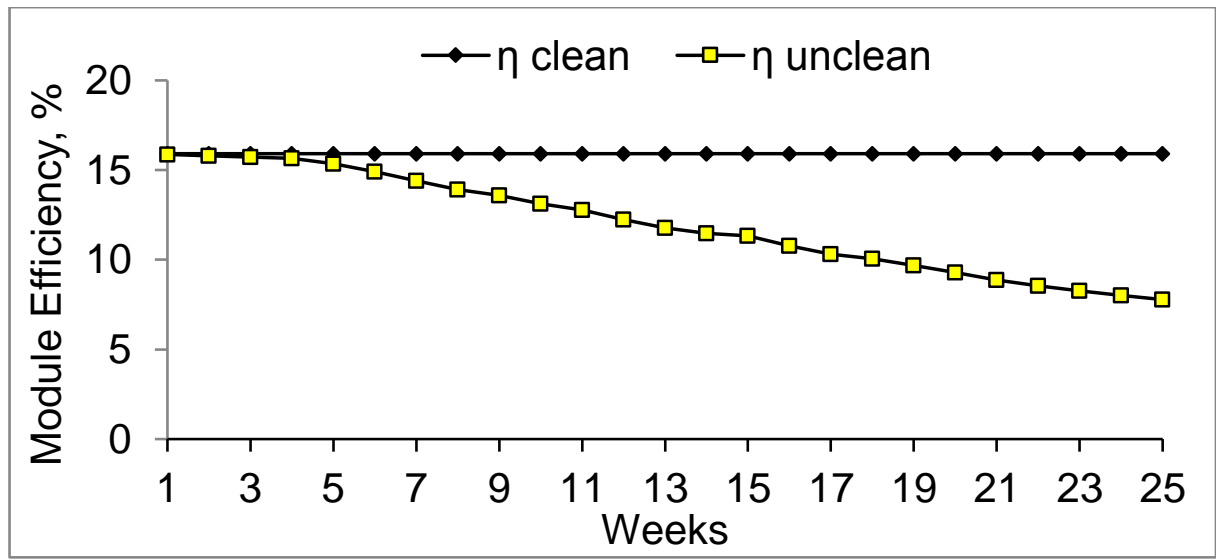

Fig (6) The Effect of dust on the module efficiency between the clean and unclean of PV modules.

\section{The effect of dust on the reduction in module efficiency of PV modules}

Fig (7) showed that the Effect of dust accumulation on reduction in module efficiency between the clean and unclean module. The results indicated that reduction in module efficiency increased continuously with increasing accumulated dust. The difference of the reduction in module efficiency for clean and unclean is very small at the first week. The 
reduction in module efficiency was $0.25 \%$. With the passage of time, the reduction in module efficiency of unclean module gradually decreased compared to the clean module. After 25 week, the reduction in module efficiency was $(51.12 \%)$.

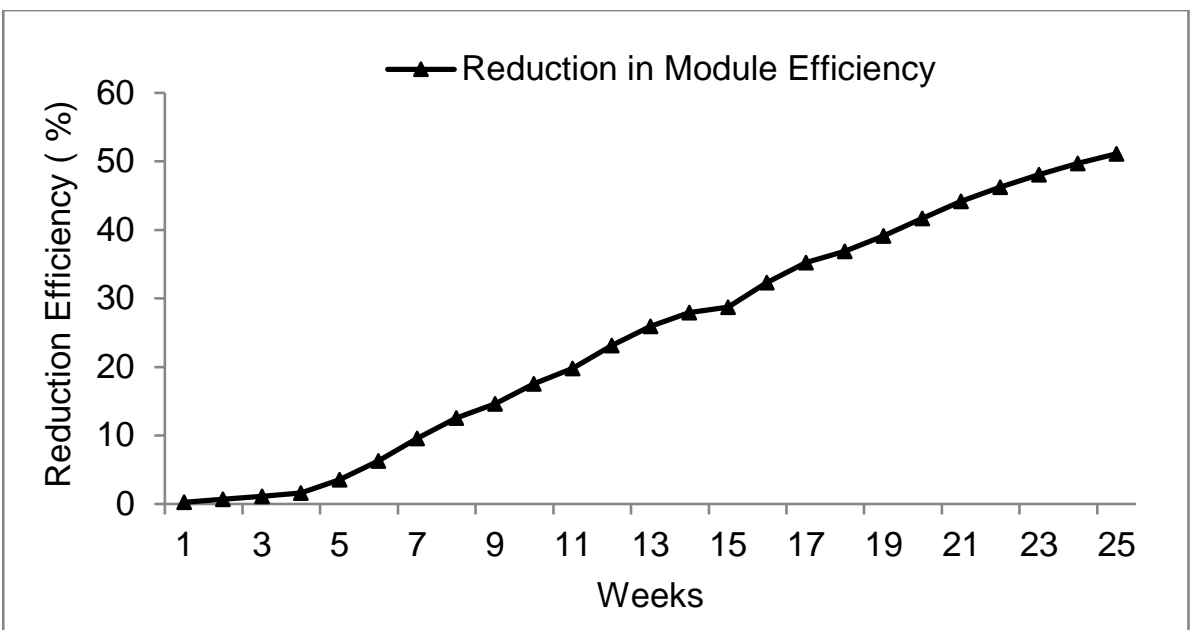

Fig (7): The Effect of dust on the reduction in module efficiency of PV modules.

\section{CONCLUSION}

The obtained results can be concluded as follows:

1 - The reduction power production up to $(51.12 \%)$.

2- The efficiency of the solar photovoltaic panel system is reduced from ( $15.9 \%$ for clean one to $7.88 \%$ for unclean module).

3- The total correction solar radiation for clean and unclean square plates of glasses was [37.4 and 18.28 (kW/ $\mathrm{m}^{2}$. week)] respectively.

4- The unclean module showed total output power (24.88\%) less than the clean module for the period of 25 weeks.

\section{Recommendation}

Cleaning is recommended once in a week or 2 weeks depending upon the rate of dust accumulation on the surface 


\section{REFERENCES}

Chaichan M. T, B. A Mohammed and H. A. Kazem (2015) Effect of pollution and cleaning on photovoltaic performance based on experimental study. International Journal of Scientific \& Engineering Research, Volume 6, Issue 4, 595 ISSN 2229-5518

Chaichan M.T., B.A. Mohammed and H. A. Kazem (2015) Effect of pollution and cleaning on photovoltaic performance based on experimental study. International Journal of Scientific \& Engineering Research, V: 6, Issue 4, (594-601)

Comsan M.N.H. (2010) solar energy perspectives in Egypt. Proceedings of the 4th Environmental Physics Conference, 10-14 March, Hurghada, Egypt. (1-11).

Grubišić-Čabo F., S. Nižetić, and T. Giuseppe Marco (2016) Photovoltaic Panels: A Review of the cooling techniques. Transactions of famena $\mathrm{xl}$ - special issue 1. ISSN 1333-1124 (63-74).

Hassan, A.H., Ali Rahoma U., and Hamdy K. Elminir (2005) Effect of airborne dust concentration on the performance of PV modules

Mekhilef S., R. Saidur b, M. Kamalisarvestani (2012) Effect of dust, humidity and air velocity on efficiency of photovoltaic cells. Renewable and Sustainable Energy Reviews 16 (2012) 2920-2925.

Mohamed A. O. and A. Hasan (2012) Effect of Dust Accumulation on Performance of Photovoltaic Solar Modules in Sahara Environment. J. Basic. Appl. Sci. Res., 2(11)11030-11036.

Samadhiya A. and Ruchi P. (2016) Analysis of PV Panels under Various Weather Conditions. International Journal of Emerging Research in Management \&Technology ISSN: 2278-9359 (Volume-5, Issue-2).

Sulaiman S. A., Haizatul H. Hussain, Nik Siti H. Nik Leh, and Mohd S. I. Razali (2011) Effects of Dust on the Performance of PV Panels. World Academy of Science, Engineering and Technology. 588593.

Zorrilla-Casanova J., M. Piliougine ,J. Carretero , P. Bernaola1 , P. Carpena , L. Mora-López and M. Sidrach-de-Cardona (2011) Analysis of dust losses in photovoltaic modules. World renewable energy congress. 8-11 May :2985-2992. 


\section{الملخص العربى}

\section{دراسة تاثير الاتربة المتراكمة على شدة الاثعاع و الواح الخلايا الثمسية

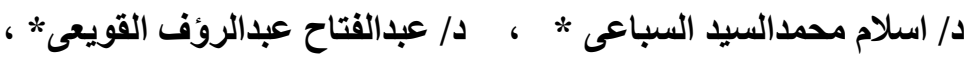

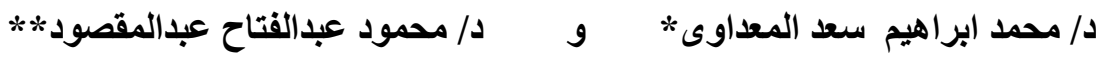

تستخدم ألواح الخلايا الثمسية لتحويل الطاقة الثمسية الى طاقة كهربية، ويعتبر شدة الاشعاع الثمسى الساقط على الخلايا هو المؤثر الرئيسى والفعال الذى يتحكم فى مقدار ما ينتج من تيار كهربى منها. و لإستقبال الإشعاع الشمسى دون عوائق يتحتم وجود الألواح الشمسية فى الخلاء

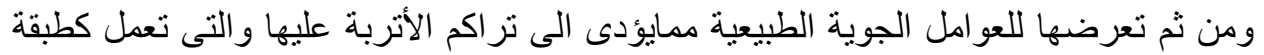

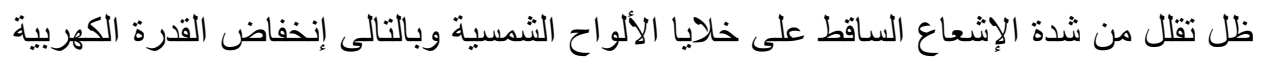

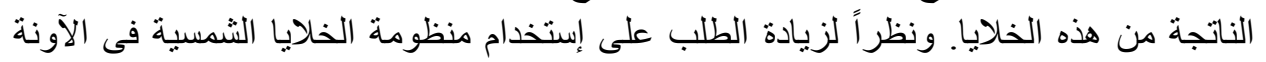
الأخيرة لما لها من مميزات عدة رغم إنخفاض كفاءتها فى إنتاج الطاقة و إرتفاع تكلفتها المبدئية،

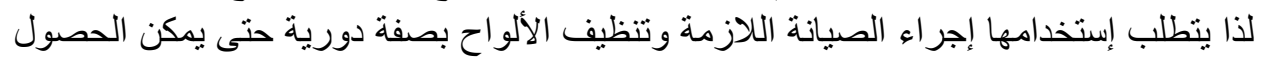
منها على أقصى قدرة كهربية ممكنة.

لذلك كان الهدف الرئيسى من هذا البحث دراسة تأثير تراكم الأتربة على الخلايا الثمسية وتأثثرها على شدة الإشعاع الثمسى الساقط على الخلايا. أجريت التجارب العملية فى مركز

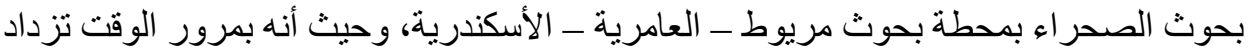
كمية الأتربة المتر اكمة على الخلايا الثمسية مما يؤدى الى انخفاض القدرة الناتجة منها. ولمعرفة

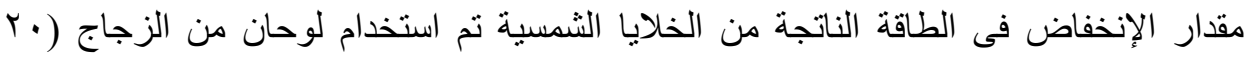

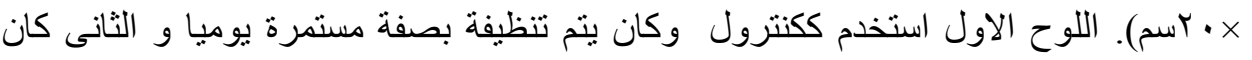

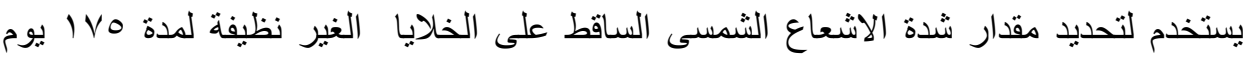

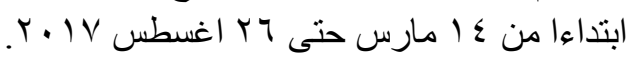
ومن خلال التجارب وجد انه حدث إنخفاض في مقدار الطاقة الناتجة من الخلايا الثمسية وصل

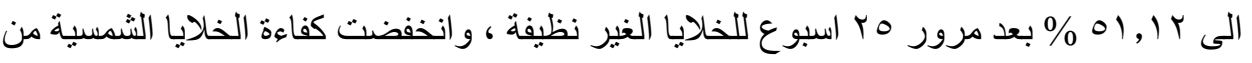

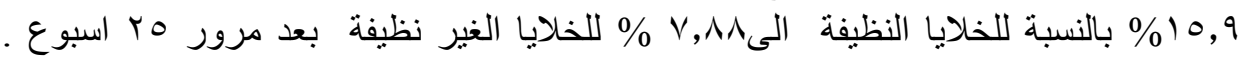

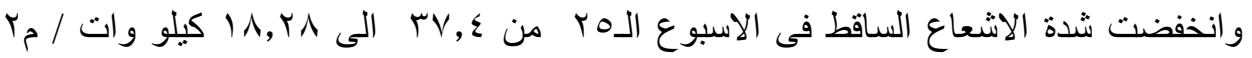

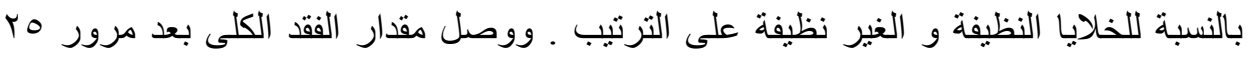

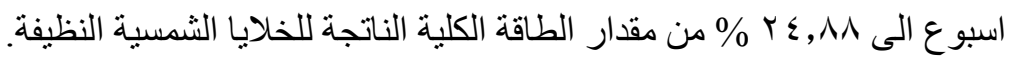

\footnotetext{
* معهر بحوث الهندسة الزراعية ـ مركز البحوث الزراعية - جيزة. ** مركز بحوث الصحراء - جيزة.
} 